\title{
MYOCARDIAL OXYGEN CONSUMPTION DURING EXERCISE IN FASTING AND LIPEMIC SUBJECTS *
}

\author{
By TIMOTHY J. REGAN, GERALD TIMMIS, $\dagger$ MURRAY GRAY, KENAN BINAK $\ddagger$ \\ AND HARPER K. HELLEMS
}
(From the Cardiovascular Research Laboratory, Department of Medicine, Wayne State Uni- versity College of Medicine, Detroit, Mich., and Seton Hall College of Medicine, Jersey City, N. J.)

(Submitted for publication June 28, 1960 ; accepted December 1, 1960)

Although total blood flow, local vascular resistance, and the tissue metabolic state are established determinants of regional blood flow, the physical composition of the perfusing fluid may substantially modify the actual flow to a given organ. The increased red cell mass of erythremia illustrates this fact, since measurements of cerebral blood flow have been among the lowest of any clinical situation (1). Altering plasma through the production of lipemia has been related to slowing of circulation in conjunctival vessels (2), and to reduced oxygen tension in the brain (3). Similarly diminished levels of myocardial blood flow and oxygen consumption were found in man during postprandial lipemia, returning to normal during postheparin lipolysis (4). This phenomenon in the resting state appeared to be concentration dependent, since there was a normal myocardial oxygen consumption at rest in patients with low lactescence values. Hence, the ability to maintain a normal response during a period of enhanced myocardial oxygen requirements has been examined in normal subjects performing moderate exercise during alimentary lipemia.

\section{MATERIALS AND METHODS}

Both the 9 normal subjects studied as controls after an overnight fast and the group of 8 studied during the postprandial state were selected during the end of the recovery phase of their illness just prior to hospital discharge. All were males and comparable in age distribution. Similar afflictions were present in both groups, usually benign, acute bacterial infections of the lung,

* Supported by Grant H-1492, National Heart Institute, Bethesda, Md.; the Michigan Heart Association; and by the Receiving Hospital Research Corp.

† Research Fellow, R. C. Mahon Foundation (1958$1960)$.

¥ Research Fellow, Rockefeller Foundation (19581959). skin or kidney. Patients with probable hemodynamic or pathologic alterations of the cardiovascular system were excluded. The fasting state was chosen as the most suitable standard for comparison rather than a nonlipid meal because both mixed and protein feeding have been associated with an elevation in cardiac output $(5,6)$. A mixed meal appears to elicit a response that is manifest by a uniform increase in blood flow to each organ, including the myocardium. Since lipid feeding fails to modify the cardiac output (6), the comparable systemic hemodynamic conditions in the fasting state would seem the more appropriate for control purposes.

The 8 subjects in the postprandial group were fed $1.5 \mathrm{~g}$ of lipid per $\mathrm{kg}$ in cream ( 36 per cent fat) about 3 hours before catheters were placed in the coronary sinus and right atrium, and a Cournand needle inserted into the brachial artery. Lumens were maintained patent by slow saline infusion, excluding the lipid-clearing agents, heparin and glucose.

At approximately 3.25 hours after eating, when a steady state had been achieved (4), the first coronary blood flow was determined by the nitrous oxide desaturation technique (7), immediately followed by simultaneous sampling for blood oxygen and carbon dioxide from the brachial artery, coronary sinus and right atrium. In addition, samples were taken for determination of the myocardial arteriovenous difference of lactate (8). Concurrent collection of expired air was performed for Fick cardiac output determination and the brachial artery pressure recorded. The validity of high atrial oxygen sampling for the cardiac output was established in a separate group of 7 resting patients in whom simultaneous atrial and pulmonary arterial samples revealed no significant difference in these mixed venous samples. Presumably, the high atrial sampling produces a sufficiently mixed sample to preclude streamline artifacts. Whether sufficient mixing at this site occurs during the enhanced flow turbulence associated with exercise would seem probable but has not been proven. However, any enhanced sampling error in individuals should be minimized in group comparisons.

Following the resting studies, patients were exercised in the supine position on a bicycle ergometer with constant resistance at a rate of about 30 revolutions per minute for 12 minutes. The flow determination was begun after 3 minutes of exercise and the above sampling procedures were repeated. 
In the group of 8 patients fed cream, serial arterial samples for plasma turbidity measurement were secured from 2.5 hours after eating, at 15 minute intervals, until exercise was begun. Samples were obtained immediately before, at 2 minutes of exercise, and again at its conclusion. These specimens were collected in chilled tubes, refrigerated, and read at 650 and $700 \mathrm{~m} \mu$ on the Coleman Junior spectrophotometer. These are the usual wave lengths employed for measuring turbidity and are far enough removed from the optimal wave lengths for plasma pigments, such as hemoglobin, to avoid interference. A comparison of the readings at both wave lengths showed the $700 \mathrm{~m} \mu$ value to be slightly lower, but the relationship of the serial turbidity values at either wave length was the same. The readings reported are those obtained at $650 \mathrm{~m} \mu$.

The development of plasma lactescence during alimentary lipemia has been alleged to be dependent upon triglyceride concentration (9). Several in vitro studies have noted a lack of correlation between these two entities. More recently, plasma turbidity has been exhibited in man after a lipid meal in the absence of significant serum triglyceride alteration (10). For these reasons, the physicochemical change in blood, shown by lactescence rather than by lipid concentration, has been correlated with the coronary hemodynamics.

A valid use of the nitrous oxide method for regional blood flow analysis in the circumstances outlined above requires that the solubility of this gas in blood be unaltered by the quantity of lipids present in the lipemic state. That the solubility of nitrous oxide may not be affected by lipid is indicated by studies of its solubility in brain where it was not significantly greater than that of blood (11). The partition coefficient, according to Kety and Schmidt (12), would be expected to change significantly only with such an altered composition of brain or blood as to be incompatible with life.

The question of possible modification of the partition coefficient in the myocardium is a separate consideration that is difficult to assess in view of the significant variability of results found in normal hearts $(7,13)$. During postprandial lipemia, if one assumes lipid concentration to be higher in blood than in heart, a possible increase in nitrous oxide blood solubility would diminish the partition coefficient and, thus, the lower than normal flows recorded (4) should actually be still lower. That nitrous oxide is not more soluble in the postprandial lipemic blood was indicated in a prior study (4) by the nitrous oxide value of arterial samples after tissue saturation, achieved by 12 minutes inhalation of this gas. The lactescent nitrous oxide values did not differ significantly from the postheparin samples which had cleared substantially. Instead of the higher value to be expected if the gas were more soluble, the mean lactescent figure was 0.2 vol per cent lower than the postheparin value. Such an unchanged solubility would also exclude an artifact in the relationship of the arteriovenous differences. In the present study, a solubility change in blood is also unlikely since the resting saturation values were identical for both groups and there was no significant difference in the exercise saturation values, the lipemic concentrations being lower by but 0.04 vol per cent. Thus blood is another tissue in which lipids do not modify $\mathrm{N}_{2} \mathrm{O}$ solubility.

For an enhanced solubility to occur in the myocardium, its lipid content would presumably achieve a concentration greater than that of blood by 3.75 hours after ingestion of lipid. Since the transport of the principal moiety involved in myocardial lipid accumulation, the free fatty acids (14), is concentration-dependent and does not rise in blood until nearly 4 hours postprandial (15), this would appear unlikely.

The specific situation with which we are concerned entails the question of whether or not the relatively low coronary flow during exercise is artifactual due to a $\mathrm{N}_{2} \mathrm{O}$ solubility change in heart muscle induced by lipid accumulation. In five of the seven lipemic individuals. plasma lactescence levels did not exceed 0.3 optical density unit, the level below which coronary flow is not found to be reduced at rest. The normal coronary flow recorded at rest implies a normal partition coefficient. It is inconceivable that within a 10 minute period of exercise the myocardium would accumulate a sufficient quantity of fat to increase the myocardial/blood partition coefficient of $\mathrm{N}_{2} \mathrm{O}$. The difference in calculated coronary blood flow during exercise would appear accounted for by the larger (by 1.28 vol per cent) integrated arteriovenous difference in the lipemic group.

\section{RESULTS}

The general hemodynamic and myocardial blood flow responses to exercise are detailed in Table I for the fasting normal subjects and in Table II for the lipemic subjects. A nearly threefold increase of total body oxygen consumption in the fasting group was associated with a rise in left ventricular myocardial oxygen usage from 8.48 to 12.56 $\mathrm{ml}$ per $100 \mathrm{~g} \mathrm{LV}$ per minute. This nearly 50 per cent change was achieved principally by a blood flow increment with a small contribution by enhanced myocardial oxygen extraction.

A significantly different response in these parameters was found in the alimentary lipemic subjects as outlined in Table II. A prior study of the lipemic state at rest (4) had indicated that a reduced myocardial blood flow existed at turbidity levels above 0.3 optical density unit. Only two of the eight lipemic subjects in the present study had resting turbidity values above this level and these had flows below the mean normal value in accord with the earlier observations.

An equivalent degree of exercise in the alimentary lipemic subjects produced a $1.53 \mathrm{ml}$ per $100 \mathrm{~g} \mathrm{LV}$ per minute increment in myocardial 
oxygen usage, significantly less than the $4.08 \mathrm{ml}$ increase in the fasting normals. The chief factor responsible was the minimal $12 \mathrm{ml}$ increase in coronary blood flow. While the flow response was not completely uniform, the arbitrary exclusion of individuals would not seem warranted. The inability to achieve an identical exercise response as exhibited by the total body oxygen usage increments must be considered an important variable. Also the somewhat greater response of the lipemic group in the other parameters that may influence myocardial oxygen usage, namely, cardiac index, pulse rate, mean arterial pressure and stroke work, suggests that any bias introduced would act against the actual observations in the lipemic group. In particular, the excessive response in the lipemic subject, M.M., was associated with a 43 per cent rise in coronary flow. With the exclusion of this subject, the coronary flow rise in the controls is of the order of 40 per cent compared to 12 per cent in the lipemic group.
A contributing factor to the observed difference in oxygen usage was the failure of an oxygen extraction increment to occur during exercise. The mean value was significantly different from the increase occurring in the fasting normal subjects $(p<0.03)$. In fact, with the exclusion of the one fasting normal subject who failed to enhance oxygen extraction, there was but one control subject whose myocardial oxygen consumption fell within the range of the lipemic group.

The finding of only one control subject in whom the oxygen extraction diminished is in accord with an earlier study in which only 2 of 13 patients had diminished oxygen extraction during exercise (16). The arterial oxygen content and capacity rose as much in the lipemic group as in the control so that oxygen availability is not limited by these factors. The higher degree of venous extraction in the lipemic group at rest may have accounted for the diminished extraction during exercise. However, a relationship between oxy-

TABLE I

Myocardial blood flow and oxygen consumption of normal fasting subjects during rest and exercise

\begin{tabular}{|c|c|c|c|c|c|c|c|c|c|c|}
\hline $\begin{array}{c}\text { Subject, } \\
\text { Age, } \\
\text { BSA * }\end{array}$ & $\begin{array}{l}\text { Coronary } \\
\text { blood } \\
\text { flow }\end{array}$ & $\begin{array}{c}\text { A-V } \\
\text { oxygen } \\
\text { diff. }\end{array}$ & $\begin{array}{c}\text { Oxygen } \\
\text { con- } \\
\text { sump- } \\
\text { tion }\end{array}$ & $\begin{array}{l}\text { Total } \\
\text { body } \\
\text { oxygen } \\
\text { con- } \\
\text { sump- } \\
\text { tion }\end{array}$ & $\begin{array}{c}\text { Cardiac } \\
\text { index }\end{array}$ & $\begin{array}{l}\text { Pulse } \\
\text { rate }\end{array}$ & $\begin{array}{c}\text { Mean } \\
\text { art. } \\
\text { pressure }\end{array}$ & $\begin{array}{l}\text { LV } \\
\text { stroke } \\
\text { work } \\
\text { index }\end{array}$ & $\begin{array}{c}\text { Art. } \\
\text { oxygen } \\
\text { content }\end{array}$ & $\begin{array}{c}\text { Art. } \\
\text { oxygen } \\
\text { saturation }\end{array}$ \\
\hline & $\underset{\min }{\mathrm{ml} / 100 \mathrm{~g} /}$ & vol \% & $\underset{\mathrm{min}}{\mathrm{ml} / \mathrm{g} /}$ & $m l / m i n$ & $L / \min$ & & $m m \mathrm{Hg}$ & $g-m$ & vol \% & $\%$ \\
\hline \multirow{2}{*}{$\begin{array}{l}\text { G.T. } \\
37 \\
1.87\end{array}$} & $\mathrm{R} \dagger \quad \mathbf{7 4}$ & 9.72 & 7.2 & 239 & 2.75 & 77 & 94 & 45.6 & 13.52 & 95.8 \\
\hline & E† 106 & 10.33 & 10.95 & 542 & 4.50 & 90 & 98 & 66.6 & 14.16 & 96.7 \\
\hline \multirow{2}{*}{$\begin{array}{l}\text { W.A. } \\
30 \\
1.59\end{array}$} & 83 & 10.12 & 8.5 & 217 & 3.54 & 88 & 80 & 43.5 & 14.60 & 95.4 \\
\hline & 160 & 11.71 & 18.7 & 474 & 5.80 & 103 & 84 & 67.9 & 15.54 & 95.0 \\
\hline \multirow{2}{*}{$\begin{array}{l}\text { R.N. } \\
39 \\
1.69\end{array}$} & 83 & 11.2 & 9.3 & 208 & 3.5 & 92 & 92 & 47.5 & 15.81 & \\
\hline & 108 & 11.3 & 12.3 & 403 & 3.9 & 118 & 95 & 38.8 & 16.25 & \\
\hline \multirow{2}{*}{$\begin{array}{l}\text { A.K. } \\
26 \\
1.83\end{array}$} & 79 & 11.07 & 8.75 & 244 & 3.33 & 83 & 93 & 50.9 & 16.11 & 93.0 \\
\hline & 122 & 11.86 & 14.40 & 621 & 5.30 & 112 & 104 & 66.9 & 16.21 & 94.3 \\
\hline \multirow{2}{*}{$\begin{array}{l}\text { F.K. } \\
41 \\
1.57\end{array}$} & 76 & 12.55 & 9.56 & 178 & 2.58 & 88 & 94 & 37.5 & 18.13 & 99.5 \\
\hline & 104 & 13.36 & 13.90 & 454 & 5.30 & 106 & 101 & 68.7 & 18.19 & 100.3 \\
\hline \multirow{2}{*}{$\begin{array}{l}\text { L.F. } \\
41 \\
1.81\end{array}$} & 83 & 10.6 & 8.84 & 222 & 3.61 & 65 & 90 & 67.9 & 14.82 & 94.5 \\
\hline & 105 & 10.2 & 10.7 & 631 & 4.75 & 93 & 102 & 71.0 & 15.41 & 95.8 \\
\hline \multirow{2}{*}{$\begin{array}{l}\text { H.W. } \\
33 \\
1.66\end{array}$} & 83 & 10.0 & 8.25 & 218 & 3.58 & 65 & 100 & 74.8 & 16.57 & 94.4 \\
\hline & 103 & 10.6 & 10.92 & 614 & 6.27 & 82 & 102 & 106.1 & 17.19 & 94.0 \\
\hline \multirow{2}{*}{$\begin{array}{l}\text { C.D. } \\
32 \\
1.75\end{array}$} & 96 & 8.85 & 8.50 & 232 & 2.94 & 74 & 99 & 53.4 & 13.55 & \\
\hline & 116 & 9.41 & 10.92 & 711 & 5.82 & 96 & 111 & 91.7 & 13.87 & 94.6 \\
\hline \multirow{2}{*}{$\begin{array}{l}\text { J.T. } \\
32 \\
1.88\end{array}$} & 79 & 9.41 & 7.44 & 219 & 3.23 & 64 & 92 & 59.4 & 15.36 & 91.9 \\
\hline & 89 & 11.15 & 10.23 & 598 & 4.20 & 89 & 95 & 61.2 & 16.59 & 95.5 \\
\hline \multirow{2}{*}{$\begin{array}{l}\text { Mean } \\
\text { values }\end{array}$} & 82 & 10.39 & 8.48 & 219 & 3.22 & 77 & 92 & 53.3 & 15.39 & 94.9 \\
\hline & 113 & 11.10 & 12.56 & 560 & 5.09 & 98 & 99 & 70.9 & 15.93 & 95.7 \\
\hline
\end{tabular}

* Age in years; BSA = body surface area in square meters.

$+R=$ values at rest; $E=$ values on exercise. 
TABLE II

Effects of alimentary lipemia upon myocardial blood flow and oxygen consumption of normal subjects at rest and during exercise

\begin{tabular}{|c|c|c|c|c|c|c|c|c|c|c|c|}
\hline $\begin{array}{c}\text { Subject, } \\
\text { Age, } \\
\text { BSA* }\end{array}$ & $\begin{array}{l}\text { Optical } \\
\text { density } \\
\text { units }\end{array}$ & $\begin{array}{l}\text { Coronary } \\
\text { blood } \\
\text { flow }\end{array}$ & $\begin{array}{c}\text { A-V } \\
\text { oxygen } \\
\text { diff. }\end{array}$ & $\begin{array}{l}\text { Oxygen } \\
\text { con- } \\
\text { sump- } \\
\text { tion }\end{array}$ & $\begin{array}{c}\text { Total } \\
\text { body } \\
\text { oxygen } \\
\text { con- } \\
\text { sump- } \\
\text { tion }\end{array}$ & $\underset{\text { index }}{\text { Cardiac }}$ & $\begin{array}{l}\text { Pulse } \\
\text { rate }\end{array}$ & $\begin{array}{l}\text { Mean } \\
\text { art. } \\
\text { pressure }\end{array}$ & $\begin{array}{c}\text { LV } \\
\text { stroke } \\
\text { work } \\
\text { index }\end{array}$ & $\begin{array}{l}\text { Art. } \\
\text { oxygen } \\
\text { content }\end{array}$ & $\begin{array}{c}\text { Art. } \\
\text { oxygen } \\
\text { saturation }\end{array}$ \\
\hline & & $\begin{array}{c}\mathrm{ml} / \\
100 \mathrm{~g} / \\
\mathrm{min}\end{array}$ & vol \% & $\begin{array}{c}\mathrm{ml} / \\
\mathrm{min}\end{array}$ & $\mathrm{ml} / \mathrm{min}$ & $L / \min$ & & $m m H g$ & $g-m$ & vol \% & $\%$ \\
\hline \multirow{2}{*}{$\begin{array}{l}\text { J.H. } \\
41 \\
1.94\end{array}$} & $\mathrm{R} \dagger 0.14$ & 77 & 13.73 & 10.50 & 232 & 2.61 & 90 & 98 & 38.4 & 14.64 & 92.0 \\
\hline & E† 0.14 & 92 & 13.24 & 12.20 & 647 & 7.06 & 107 & 108 & 96.8 & 15.29 & 96.7 \\
\hline \multirow{2}{*}{$\begin{array}{l}\text { J.S. } \\
41 \\
1.90\end{array}$} & 0.18 & 82 & 9.33 & 7.66 & 267 & 2.52 & 90 & 76 & 28.9 & 16.51 & 97.2 \\
\hline & 0.35 & 70 & 8.36 & 5.85 & 692 & 6.28 & 105 & 80 & 65.1 & 16.30 & 93.4 \\
\hline \multirow{2}{*}{$\begin{array}{l}\text { O.B. } \\
36 \\
1.68\end{array}$} & & \pm & 11.55 & & 232 & & & & & 15.54 & \\
\hline & 0.34 & & 11.36 & & 700 & & & & & 15.93 & \\
\hline \multirow{2}{*}{$\begin{array}{l}\text { M.M. } \\
23 \\
1.84\end{array}$} & 0.26 & 72 & 14.35 & 10.33 & 244 & 3.34 & 62 & 80 & 58.6 & 18.00 & 96.8 \\
\hline & 0.48 & 103 & 13.42 & 13.82 & 865 & 9.89 & 110 & 102 & 124.7 & 17.72 & 96.0 \\
\hline \multirow{2}{*}{$\begin{array}{l}\text { E.P. } \\
36 \\
2.02\end{array}$} & 0.29 & 81 & 12.90 & 10.45 & 230 & 2.85 & 94 & 90 & 37.0 & 17.54 & 94.9 \\
\hline & 0.42 & 101 & 12.52 & 12.65 & 484 & 3.51 & 116 & 95 & 38.5 & 17.78 & 96.4 \\
\hline \multirow{2}{*}{$\begin{array}{l}\text { C.W. } \\
37 \\
1.75\end{array}$} & 0.29 & 83 & 10.60 & 8.36 & 231 & 4.15 & 84 & 83 & 53.8 & 18.17 & 92.3 \\
\hline & 0.46 & 77 & 12.26 & 9.44 & 367 & 4.55 & 91 & 92 & 62.5 & 18.61 & 93.9 \\
\hline \multirow{2}{*}{$\begin{array}{l}\text { J.S. } \\
26 \\
1.86\end{array}$} & 0.62 & 65 & 11.78 & 7.60 & 295 & 4.09 & 74 & 91 & 68.4 & 16.29 & 96.4 \\
\hline & 1.20 & 81 & 11.17 & 9.04 & 674 & 5.59 & 102 & 100 & 74.5 & 16.70 & 99.6 \\
\hline \multirow{2}{*}{$\begin{array}{l}\text { W.P. } \\
33 \\
1.81\end{array}$} & 0.78 & 68 & 12.95 & 8.87 & 317 & 3.11 & 89 & 82 & 39.08 & 16.46 & 98.9 \\
\hline & 0.92 & 87 & 13.29 & 11.51 & 711 & 5.24 & 104 & 92 & 63.16 & 16.19 & 97.9 \\
\hline \multirow{2}{*}{$\begin{array}{l}\text { Mean } \\
\text { values }\end{array}$} & 0.34 & 75 & 12.14 & 9.11 & 256 & 3.23 & 83 & 85 & 46.31 & 16.64 & 95.5 \\
\hline \multirow{2}{*}{\multicolumn{2}{|c|}{$\begin{array}{l}\text { Statistical } \\
\text { significance }\end{array}$}} & 87 & 11.95 & 10.64 & 642 & 6.01 & 105 & 99 & 75.03 & 16.75 & 96.3 \\
\hline & & $\mathrm{p}<0.05$ & $\mathrm{p}<0.03$ & $\mathrm{p}<0.03$ & NS & NS & NS & NS & NS & NS & NS \\
\hline
\end{tabular}

* Age in years; $\mathbf{B S A}=$ body surface area in square meters.

$\dagger \mathbf{R}=$ values at rest; $\mathbf{E}=$ values on exercise.

Nonpaired comparison between changes in the fasting and lipemic group. NS = not statistically significant.

gen extraction during exercise and the level at rest has not been found (16). A greater increment has actually been observed in patients with resting extractions above 11.0 vol per cent than in those below. Furthermore, the relatively low coronary blood flow in lipemic subjects would usually be expected to enhance oxygen extraction.

It is notable that in all but one lipemic subject the turbidity of the plasma was increased during the period of exercise, by a mean of 0.13 optical density unit for the group. A significant rise was not found in five fasting subjects, but at turbidity levels of $0.04 \mathrm{U}$ a proportionate lipid rise may occur in this group that is not substantial enough to influence optical density. The rise in the lipemic group occurred within a period of $12 \mathrm{~min}$ utes and may be partially accounted for by reason of sampling during the postprandial phase of rising plasma lipid concentration. This degree of change, however, has not been found within a similar period in sequential samples from resting lipemic patients, the mean rise of $0.02 \pm 0.03$ bearing no significance. This phenomenon of rapidly enhanced plasma turbidity during exercise has been observed earlier (17).

Since metabolic factors within the myocardium may exert a controlling influence upon myocardial oxygen, the respiratory quotient of the heart has been employed as an approximate index

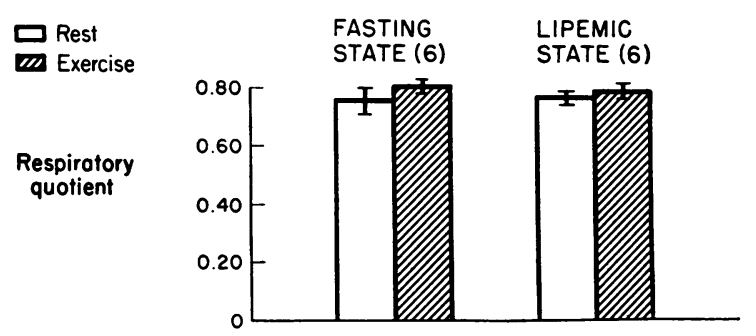

Fig. 1. Myocardial Respiratory guotient at Rest and DURING EXERCISE. 


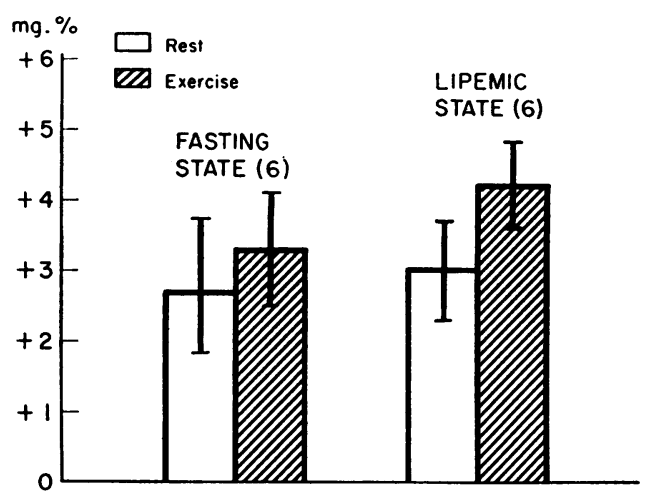

Fig. 2. Myocardial arteriovenous difference of LACTATE.

of relative foodstuff utilization by the myocardium. As indicated in Figure 1, the resting respiratory quotient was nearly the same in both the fasting and alimentary lipemic groups, reflecting a similar proportionately high usage of lipid in these circumstances. A slight, but parallel, rise was seen during exercise, so that no difference in foodstuff utilization would account for the discrepancy in myocardial oxygen usage.

To assess the possible presence of myocardial ischemia during the course of exercise in the lipemic subjects, an attempt to detect enhanced glycolysis by the heart was made by appraising lactate arteriovenous differences. As depicted in Figure 2 , no enhancement of lactate production by the heart occurred. The slightly greater increase in the positive arteriovenous difference of the lipemic group appeared due to higher arterial concentrations.

\section{DISCUSSION}

The lower than normal level of oxygen consumption in the myocardium of lipemic subjects during exercise agrees with the concept that the blood flow to certain organs may be impaired by a change in the physical consistency or viscosity of blood. Thus, reduced flow to the brain (1) and myocardium (18) have been observed in polycythemia vera. That this reduced regional blood flow is more a function of viscosity change than of increased oxygen carrying capacity is suggested by the effects of acutely increasing red cell mass. Despite a rise in left heart work in this situation, the simultaneous reduction in coronary flow is not associated with a sufficient oxygen extraction increment to increase myocardial oxygen uptake
(19). Further, the reduction in cardiac output during normovolemic polycythemia is disproportionately great for the degree of hematocrit rise, suggesting a viscosity effect (20).

The altered physical state of plasma, shown by lactescence during alimentary lipemia, has been associated with reduced oxygen tensions in the brain (3) and skeletal muscle (21), and with a lower level of myocardial oxygen consumption in the resting normal subject (4). One cannot exclude an unknown tissue metabolic influence in the production of this effect, although the rather parallel respiratory quotient changes found in the myocardium of both groups during the exercise period provide some evidence against a substantial metabolic change in this organ. That the reduced oxygen usage during lipemia may be a circulatory phenomenon is suggested by the visual observation of slowing of circulation with red cell aggregation in the conjunctival vessels of man (2).

The different methodologies used in the regional studies cited make it difficult to gainsay the conclusion that the blood flow to certain organs is reduced during lipemia. The normal cardiac output, however, implies that other regions yet to be measured undergo a flow increment. A similar discrepancy seems to exist in polycythemia vera where certain regions have reduced blood flow $(1,18)$, but total blood flow has been found to be elevated (22).

The relatively low blood flow through the coronary vessels during lipemia appears to reflect a rise in total resistance to flow, as the difference in arterial pressure rise of both groups was not significant, the absolute levels in fact being the same during exercise. Since a differential effect of extravascular compression upon the coronary vessels would seem unlikely as an explanation for the coronary flow difference, the alleged viscosity increment during alimentary lipemia (23) would appear to be the major determinant of the change in total resistance.

An increase in the ratio of left ventricular external work to oxygen consumption implies a greater mechanical efficiency in exercised lipemic than in fasting control subjects. This would appear to be a real difference since the discrepancy in oxygen usage between the two groups is too large to be accounted for solely by a lower oxygen 
usage during diastole when no external work is performed. Moreover, this degree of limitation of myocardial oxygen usage in normals was not sufficient to impair mechanical function of the heart, since lipemic patients performed as well during exercise as nonlipemic subjects. This conclusion would appear warranted even without filling pressure data, since, if one assumed a 10 $\mathrm{mm} \mathrm{Hg}$ rise on exercise in lipemic subjects above that occurring in the nonlipemic subjects, the percentage increase in left heart work would be comparable in both groups.

The lack of development of an oxygen debt in this circumstance is paralleled by other situations in which mechanical work is proportionately greater than the oxygen usage of the heart. Thus, chronic atrioventricular block has been associated with a doubling of efficiency in the canine heart compared with vagotomized controls (24). A fourfold enhancement of left ventricular mechanical efficiency has been observed during intravascular volume expansion without evidence of a significant oxygen debt (25). There is also some indication that in high output states estimated efficiency during exercise may as much as double without evidence of cardiac dysfunction (16). Therefore, the apparent 65 per cent increase in efficiency in lipemic subjects during exercise is compatible with normal cardiac function, and does not induce ischemic effects in the normal heart. This fact is supported by the data on myocardial lactate extraction.

While the quantity of lipid fed to these subjects is abnormal, the finding of reduced myocardial oxygen usage in those with low lactescence values, demonstrable only on exercise, is of some interest. Moderate fat loads, such as might be eaten in a normal meal, are apparently reflected by some plasma turbidity during the period of absorption (26). If such a response reaches the degree of lactescence reported here, it is conceivable that a normal mixed meal may be attended by a relatively reduced coronary flow during exercise.

\section{SUMMARY}

An evaluation of the effects of alimentary lipemia upon myocardial performance during exercise has been undertaken by comparing the response of nine fasting and eight lipemic subjects. In the former group, a nearly threefold rise of total body oxygen consumption during exercise was attended by a $4.1 \mathrm{ml}$ per $100 \mathrm{~g}$ per minute increase in left ventricular oxygen consumption. Similar exercise in the lipemic subjects, 3.5 hours post prandial, produced a significantly smaller increment of $1.53 \mathrm{ml}$ per $100 \mathrm{~g}$ left ventricle per minute. This limited response was largely accounted for by a smaller coronary blood flow rise, presumably due to a change in the physical composition of blood during plasma lactescence. Interference with the process of oxygen diffusion across myocardial capillaries is implied by the fact that on exercise the usual enhancement of myocardial oxygen extraction failed to occur in the lipemic group.

Despite these findings, the mechanical performance of the heart was normal and lipemia was associated with no evidence of myocardial ischemia, as judged by lactate extractions. The possibility is considered that this lipemic effect on myocardial blood flow and oxygen consumption during exercise may occur at low plasma lactescence levels following a more usual meal.

\section{REFERENCES}

1. Kety, S. S. Circulation and metabolism of the human brain in health and disease. Amer. J. Med. 1950, 8, 205.

2. Williams, A. V., Higginbotham, A. C., and Knisely, M. H. Increased blood cell agglutination following injection of fat, a factor contributing to cardiac ischemia, coronary insufficiency, and anginal pain. Angiology 1957, 8, 29.

4. Regan, T. J., Binak, K., Gordon, S., DeFazio, V., and Hellems, H. K. The modification of myocardial blood flow and oxygen consumption during postprandial lipemia and heparin-induced lipolysis (abstract). J. clin. Invest. 1959, 38, 1033.

5. Reininger, E. J., and Sapirstein, L. A. Effect of digestion on distribution of blood flow in the rat. Science 1957, 126, 1176.

6. Reininger, E. J., and Nutik, S. Determination of cardiac output following a meal in the unanesthetized dog. Fed. Proc. 1960, 19, 118.

7. Goodale, W. T., and Hackel, D. B. Measurement of coronary blood flow in dogs and man from rate of myocardial nitrous oxide desaturation. Circulat. Res. 1953, 1, 502.

8. Barker, S. B., and Summerson, W. H. The colorimetric determination of lactic acid in biological material. J. biol. Chem. 1948, 138, 535.

9. Albrink, M. J., Man, E. B., and Peters, J. P. The relation of neutral fat to lactescence of serum. J. clin. Invest. 1955, 34, 147. 
10. Dole, V. P., James, A. T., Webb, J. P. W., Rizack, M. A., and Sturman, M. F. The fatty acid patterns of plasma lipids during alimentary lipemia. J. clin. Invest. 1959, 38, 1544.

11. Kety, S. S., Harmel, M. H., Broomell, H. T., and Rhode, C. B. The solubility of nitrous oxide in blood and brain. J. biol. Chem. 1948, 173, 487.

12. Kety, S. S., and Schmidt, C. F. The nitrous oxide method for the quantitative determination of cerebral blood flow in man: Theory, procedure and normal values. J. clin. Invest. 1948, 27, 476.

13. Eckenhoff, J. E., Hafkenschiel, J. H., Harmel, M. H., Goodale, W. T., Lubin, M., Bing, R. J., and Kety, S. S. Measurement of coronary blood flow by the nitrous oxide method. Amer. J. Physiol. 1948, 152, 356.

14. Gordon, R. S., Jr. Unesterified fatty acid in human blood plasma. II. The transport function of unesterified fatty acid. J. clin. Invest. 1957, 36, 810.

15. Spitzer, J. J., and Miller, H. L. Unesterified fatty acids and lipid transport in dogs. Proc. Soc. exp. Biol. (N. Y.) 1956, 92, 124.

16. Lombardo, T. A., Rose, L., Taeschler, M., Tuluy, S., and Bing, R. J. The effect of exercise on coronary blood flow, myocardial oxygen consumption and cardiac efficiency in man. Circulation 1953, 7, 71.

17. Patterson, J. W. T. Blood-fat and exercise. Biochem. J. 1927, 21, 958.

18. Regan, T. J., Frank, M. J., Lehan, P. H., and Hellems, H. K. Influence of red cell mass on myo- cardial blood flow and oxygen uptake. Clin. Res. 1960, 8, 367.

19. Kobelt, C., Christensen, R. C., Ord, J. W., Powsner, R., Wada, T., Regan, T. J., and Hellems, H. K. The coronary circulation in the anemic human subject. Clin. Res. 1957, 5, 292.

20. Richardson, T. Q., and Guyton, A. C. Effects of polycythemia and anemia on cardiac output and other circulatory factors. Amer. J. Physiol. 1959, 197, 1167.

21. Joyner, C. R., Horwitz, O., and Williams, P. G. Effect of lipemia on tissue oxygen tension (abstract). Circulation 1959, 20, 716.

22. Cobb, L. A., and Kramer, R. J. Circulatory effects of chronic hypervolemia in polycythemia vera (abstract). Circulation 1959, 20, 679.

23. Swank, R. L. Changes in the blood produced by a fat meal and by intravenous, heparin. Amer. J. Physiol. 1951, 164, 798.

24. Scott, J. C., and Balourdas, T. A. Effect of atropine and of chronic A-V block on coronary blood flow in the dog. Amer. J. Physiol. 1960, 198, 145.

25. Sarnoff, S. J., Case, R. B., Welch, G. H., Jr., Braunwald, E., and Stainsby, W. N. Performance characteristics and oxygen debt in a nonfailing, metabolically supported, isolated heart preparation. Amer. J. Physiol. 1958, 192, 141.

26. Gage, S. H., and Fish, P. A. Fat digestion, absorption, and assimilation in man and animals as determined by the dark-field microscope, and a fat-soluble dye. Amer. J. Anat. 1924, 34, 1.

\section{ANNOUNCEMENT OF MEETINGS}

The Fifty-Third Annual Meeting of THE AMERICAN SOCIETY FOR CLINICAL INVESTIGATION will be held in Atlantic City, N. J., on Sunday afternoon and evening, April 30, 1961, in the Chalfonte-Haddon Hall (jointly with the AFCR) ; and on Monday, May 1, at 9:00 a.m., at the Casino Theater on the Steel Pier.

The Eighteenth Annual Meeting of THE AMERICAN FEDERATION FOR CLINICAL RESEARCH will be held in Atlantic City, N. J., on Sunday, April 30, 1961, at 9:00 a.m., at the Casino Theater on the Steel Pier. On Sunday afternoon and evening, April 30,1961, a joint sectional meeting with THE AMERICAN SOCIETY FOR CLINICAL INVESTIGATION will be held in rooms in the Chalfonte-Haddon Hall.

THE ASSOCIATION OF AMERICAN PHYSICIANS will hold its Seventy-Fourth Annual Meeting in Atlantic City, N. J., at the Casino Theater on the Steel Pier on Tuesday, May 2, 1961, at 9:30 a.m., and in the Carolina Room, Chalfonte-Haddon Hall, on Wednesday, May 3, 1961, at $9: 30$ a.m. 